\title{
Alterations to penicillin-binding proteins 1A, 2B and $2 X$ amongst penicillin-resistant clinical isolates of Streptococcus pneumoniae serotype 23F from the nasopharyngeal flora of children
}

\author{
AGNES FERRONI and PATRICK BERCHE \\ Service de Microbiologie, CHU Necker-Enfants-Malades, 149 rue de Sèvres, 75015 Paris, France
}

\begin{abstract}
Various amino acid substitutions were identified in the three major penicillin-binding proteins (PBP1A, PBP2B and PBP2X) of eight clinical isolates of Streptococcus pneumoniae serotype $23 \mathrm{~F}$ collected from children. The particular changes related to the level of penicillin resistance. Alterations were detected in an isolate with a penicillin MIC as low as $0.06 \mathrm{mg} / \mathrm{L}$. These results confirm that the level of penicillin resistance in pneumococci reflects with sequential alterations of PBPs in clinical isolates.
\end{abstract}

\section{Introduction}

The emergence and the rapid spread of penicillinresistant Streptococcus pneumoniae presents a serious public health problem. The penicillin resistance is due to reduced affinity of one or more penicillin-binding proteins (PBPs). PBPs are the target enzymes of penicillin and catalyse the last steps of peptidoglycan biosynthesis. They are multifunctional enzymes containing a penicillin-binding domain homologous to that of $\beta$-lactamases, with three conserved motifs in a close spatial relationship. These sequences form the active centre and comprise the tetrad SXXK (which has the active site serine), the SXN box and the KT(S)G triad [1]. PBPs form stable covalent complexes with $\beta$ lactam via the active serine of the SXXK box [2].

Amino acid sequence alterations cause conformational changes in PBPs and may alter the shape of the active site $[3,4]$. In pneumococci, the high mol. wt PBPs 1A $(79.7 \mathrm{kDa}), 2 \mathrm{~B}(82.3 \mathrm{kDa})$ and $2 \mathrm{X}(82.3 \mathrm{kDa})$ are those most involved in penicillin resistance $[5,6]$ and the three-dimensional structure of PBP2X has been determined recently, allowing a better understanding of its interactions with $\beta$-lactams [7].

Laboratory-selected mutants of pneumococci have only point mutations in their PBP genes, but resistance in clinical isolates is acquired via genetic transformation

Received 26 Oct. 2000; revised version accepted 26 March 2001.

Corresponding author: Professor P. Berche (e-mail:berche@ necker.fr).
[8], yielding mosaic genes with regions diverging up to $25 \%$ from the homologous sequence of susceptible isolates, leading to substitution of c. $10 \%$ of the amino acids $[1,2,9]$. The sources of these DNA blocks are oral streptococci, including $S$. oralis and $S$. mitis, which harbour $p b p$ genes homologous to those of $S$. pneumoniae [1,9]. Most studies on the PBPs of wildtype clinical isolates have examined only one or two PBPs [4, 10-15]. The present work sequenced the three major $p b p$ genes (pbpla, pbp2b and $p b p 2 x$ ) in unrelated clinical pneumococci collected from the nasopharyngeal flora of young children in France, where the rate of penicillin-resistant pneumococci has increased considerably in recent years [16].

\section{Materials and methods}

Seven epidemiologically unrelated wild-type isolates of $S$. pneumoniae serotype $23 \mathrm{~F}$ were collected between 1993 and 1998 from the nasopharyngeal flora of children aged $<3$ years in different parts of France. The first penicillin-resistant serotype 23F clinical strain (BM4200) to be isolated in France was also included; this organism dated from 1978 [17]. Minimal inhibitory concentrations (MICs) of penicillin G were determined on Mueller-Hinton Agar (bioMérieux, Marcy l'Etoile, France) containing lysed horse blood 5\%. Incubation was at $37^{\circ} \mathrm{C}$ for $18 \mathrm{~h}$ in an atmosphere supplemented with $\mathrm{CO}_{2} 5 \%$. Serogroups were determined with specific antisera from the Statens-Serum Institute (Copenhagen, Denmark). Pulsed-field gel electrophoresis of Sma I-restricted chromosomal DNA was used to examine strain relatedness, as described previously for 
$S$. pneumoniae [18]. The penicillin-susceptible $S$. pneumoniae strain R6 was used as a control [19].

The nucleotide sequences of the penicillin-binding domains of the $p b p 1 a, p b p 2 b$ and $p b p 2 x$ genes were determined by PCR with the following primers: (1) pbpla: 5'GGTGCCTTCCCTCAAATTCC3' and 5'TTCTCAGGCTTTTGTTAAGC3'; (2) pbp2b: 5'GA TCCTCTAAATGATTCTCAGGTGG3' and 5'GGAAT CCGGCGTCAACTCTC3'; (3) pbp $2 x: 5^{\prime}$ TGCCAATT CACACGATTTGC3' and 5'TCACAATTCCAGCACT GATG3'. PCR was performed in a Perkin-Elmer 9600 Thermocycler (Norwalk, CT, USA) with 40 cycles of $20 \mathrm{~s}$ at $94^{\circ} \mathrm{C}, 20 \mathrm{~s}$ at $55^{\circ} \mathrm{C}, 45 \mathrm{~s}$ at $72^{\circ} \mathrm{C}$, and a final extension of $10 \mathrm{~min}$ at $72^{\circ} \mathrm{C}$. The resulting amplicons were purified by filtration through an S-400 HR Microspin ${ }^{\circledR}$ purification column (Pharmacia Biotech, Uppsala, Sweden) and both strands were sequenced in an ABI-Prism 310 Sequencer (Perkin-Elmer, Foster City, Ca, USA), with a Big Dye Terminator Cycle Sequencing Kit (Perkin-Elmer). Sequence alignments were performed with the multiple sequence alignment program Clustal W version 1.8 (Infobiogene). Sequences were compared with those of the susceptible reference strain R6.

\section{Results and discussion}

The study determined the sequences of the three major genes ( $p b p 1 a, p b p 2 b$ and $p b p 2 x$ ) involved in the penicillin resistance of $S$. pneumoniae in each of eight wild-type isolates of serotype $23 \mathrm{~F}$. All the isolates were collected from children. These included strain BM4200, which is the first example of a penicillin-resistant serotype $23 \mathrm{~F}$ isolate from France. Although all were of serotype $23 \mathrm{~F}$, the eight isolates gave diverse PFGE profiles (Fig. 1) and varied in their level of penicillin resistance, with MICs from $<0.0075 \mathrm{mg} / \mathrm{L}$ to $8 \mathrm{mg} / \mathrm{L}$.

As previously reported for other strains [3, 12, 15], the nucleotide and peptide sequences of the genes and encoded PBPs were almost identical between the susceptible clinical strain 1261 (MIC $<0.0075 \mathrm{mg} / \mathrm{L}$ ) and R6 ( $\sim 0.3 \%$ divergence) but - for the other clinical organisms - the proportion of peptide substitutions rose roughly in line with the level of penicillin resistance (Table 1). Similar substitution rates to those found here have been reported previously for penicillin-resistant strains, from serogroups 6 and 19 [4]. The divergence from the sequences for strain R6 was greatest in the highly resistant isolate 22861 (MIC $8 \mathrm{mg} / \mathrm{L}$ ) in which all three PBPs were affected, with an overall substitution rate of $8 \%$ (Table 1). Nevertheless, a high number of substitutions was found in PBPs 2B and $2 \mathrm{X}$ of isolate 1513 (7.2\% and $7.3 \%$, respectively), which contrasts with the low MIC recorded $(0.06 \mathrm{mg} / \mathrm{L})$. Several of the sequence changes found in this latter isolate may be irrelevant to penicillin resistance.

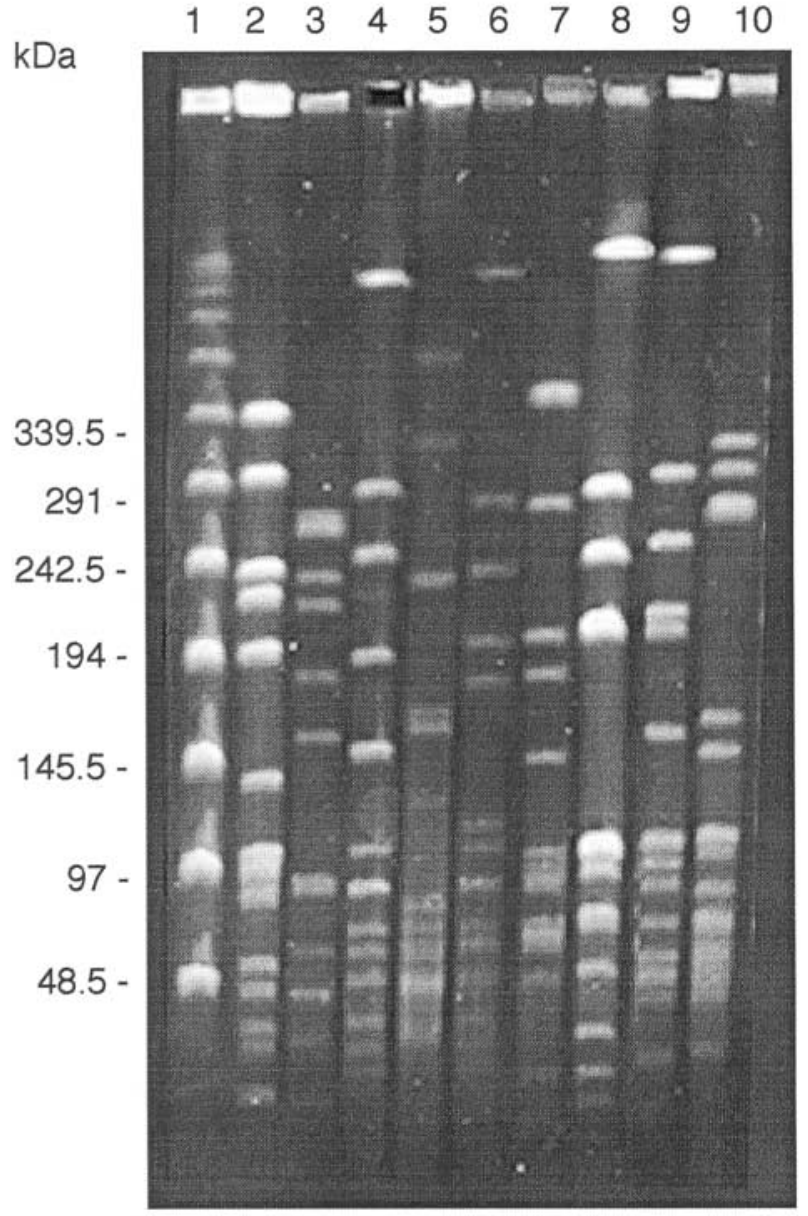

Fig. 1. Pulsed-field electrophoresis of SmaI-digested DNA of strains of $S$. pneumoniae belonging serogroup 23F. Lane 1, mol. wt marker $(\lambda)$; 2 , strain R6; 3, strain $1261 ; \mathbf{4}$, strain $1513 ; \mathbf{5}$, strain $1465 ; \mathbf{6}$, strain $1258 ; \mathbf{7}$, strain 1053; 8, strain BM4200; 9, strain 1470; 10, strain 22861.

The sequence of PBP1A was altered in an isolate with an MIC of $0.12 \mathrm{mg} / \mathrm{L}$, a lower threshold value than that reported previously $[15,20]$. Most of these alterations were adjacent to the motifs involved in the catalytic site, i.e., STMK, SRN, KTG, and included a T371A substitution inside the active site STMK motif (Fig. 2). This change is known to contribute to penicillin resistance $[10,15,20]$. The block NTGY (574-577) was found in the PBP1A sequence of all strains with penicilllin MICs $>0.5 \mathrm{mg} / \mathrm{L}$, as described previously in strains from serogroups 6,19 and 23 [15].

Most amino acid substitutions in PBP2B were located in the vicinity of the SVVK (192-195), and SSN (249-251) sites (Fig. 2). By analogy with the class A $\beta$-lactamases of Streptomyces albus, this region may form a pocket where the phenyl group of the $6^{\prime}$ acyl substituent of penicillin interacts with the PBP [3]. Two substitutions in PBP2B were associated with decreased affinity for penicillin: specifically all the isolates with MICs $>0.06 \mathrm{mg} / \mathrm{L}$ had both substitutions T252A and 
Table 1. Nucleotide and peptide sequence substitutions in PBPs from eight clinical isolates of S. pneumoniae in relation to their levels of resistance to penicillin

\begin{tabular}{|c|c|c|c|c|c|c|c|c|c|c|}
\hline \multirow[b]{2}{*}{ Isolate no. } & \multicolumn{5}{|c|}{ Genes: number of nucleotide changes (\%) } & \multicolumn{5}{|c|}{ Proteins: number of amino acid changes (\%) } \\
\hline & $\begin{array}{c}\text { Origin } \\
\text { and MIC } \\
(\mathrm{mg} / \mathrm{L})\end{array}$ & $\begin{array}{r}p b p 1 \mathrm{a} \\
2154 \mathrm{bp}\end{array}$ & $\begin{array}{c}p b p 2 \mathrm{~b} \\
1460 \mathrm{bp}\end{array}$ & $\begin{array}{c}p b p 2 \mathrm{x} \\
2250 \mathrm{bp}\end{array}$ & $\begin{array}{c}\text { Total } \\
5864 \mathrm{bp}\end{array}$ & $\begin{array}{l}\text { PBP1A } \\
718 \text { aa }\end{array}$ & $\begin{array}{l}\text { PBP2B } \\
486 \text { aa }\end{array}$ & $\begin{array}{l}\text { PBP2X } \\
750 \text { aa }\end{array}$ & $\begin{array}{c}\text { Total } \\
1954 \text { aa }\end{array}$ & $\begin{array}{c}\text { GenBank } \\
\text { accession } \\
\text { nos }\end{array}$ \\
\hline R6 & $<0.0075$ & - & - & - & - & - & - & - & - & \\
\hline 1261 & $\begin{array}{l}\text { France } 1993 \\
\quad<0.0075\end{array}$ & $\begin{array}{r}11 \\
(0.5)\end{array}$ & $\begin{array}{r}4 \\
(0.3)\end{array}$ & $\begin{array}{r}7 \\
(0.3)\end{array}$ & $\begin{array}{r}22 \\
(0.4)\end{array}$ & $\begin{array}{c}4 \\
(0.6)\end{array}$ & $\begin{array}{c}1 \\
(0.2)\end{array}$ & $\begin{array}{c}1 \\
(0.1)\end{array}$ & $\begin{array}{c}6 \\
(0.3)\end{array}$ & $\begin{array}{l}\text { AF210745 } \\
\text { AF210761 } \\
\text { AF210753 }\end{array}$ \\
\hline 1513 & $\begin{array}{c}\text { France } 1993 \\
0.06\end{array}$ & $\begin{array}{r}10 \\
(0.5)\end{array}$ & $\begin{array}{c}177 \\
(12.1)\end{array}$ & $\begin{array}{c}252 \\
(11.2)\end{array}$ & $\begin{array}{r}439 \\
(7.5)\end{array}$ & $\begin{array}{c}5 \\
(0.7)\end{array}$ & $\begin{array}{c}35 \\
(7.2)\end{array}$ & $\begin{array}{c}55 \\
(7.3)\end{array}$ & $\begin{array}{c}95 \\
(4.9)\end{array}$ & $\begin{array}{l}\text { AF210746 } \\
\text { AF210762 } \\
\text { AF210754 }\end{array}$ \\
\hline 1465 & $\begin{array}{c}\text { France } 1993 \\
0.12\end{array}$ & $\begin{array}{c}221 \\
(10.2)\end{array}$ & $\begin{array}{r}90 \\
(6.2)\end{array}$ & $\begin{array}{r}154 \\
(6.8)\end{array}$ & $\begin{array}{r}465 \\
(7.9)\end{array}$ & $\begin{array}{c}39 \\
(5.4)\end{array}$ & $\begin{array}{c}14 \\
(2.9)\end{array}$ & $\begin{array}{c}27 \\
(3.6)\end{array}$ & $\begin{array}{c}81 \\
(4.1)\end{array}$ & $\begin{array}{l}\text { AF210747 } \\
\text { AF210763 } \\
\text { AF210755 }\end{array}$ \\
\hline 1258 & $\begin{array}{c}\text { France } 1993 \\
0.25\end{array}$ & $\begin{array}{c}263 \\
(12.2)\end{array}$ & $\begin{array}{r}62 \\
(4.2)\end{array}$ & $\begin{array}{r}139 \\
(6.2)\end{array}$ & $\begin{array}{r}464 \\
(7.9)\end{array}$ & $\begin{array}{c}69 \\
(9.6)\end{array}$ & $\begin{array}{c}13 \\
(2.7)\end{array}$ & $\begin{array}{c}25 \\
(3.3)\end{array}$ & $\begin{array}{c}107 \\
(5.5)\end{array}$ & $\begin{array}{l}\text { AF210748 } \\
\text { AF210764 } \\
\text { AF210756 }\end{array}$ \\
\hline 1053 & $\begin{array}{c}\text { France } 1993 \\
0.5\end{array}$ & $\begin{array}{c}250 \\
(11.6)\end{array}$ & $\begin{array}{r}80 \\
(5.5)\end{array}$ & $\begin{array}{r}21 \\
(0.9)\end{array}$ & $\begin{array}{l}351 \\
(6)\end{array}$ & $\begin{array}{c}56 \\
(7.8)\end{array}$ & $\begin{array}{c}11 \\
(2.3)\end{array}$ & $\begin{array}{l}45 \\
(6)\end{array}$ & $\begin{array}{c}120 \\
(6.1)\end{array}$ & $\begin{array}{l}\text { AF210749 } \\
\text { AF210765 } \\
\text { AF210757 }\end{array}$ \\
\hline BM 4200 & $\begin{array}{c}\text { France } 1978 \\
0.5\end{array}$ & $\begin{array}{r}74 \\
(3.4)\end{array}$ & $\begin{array}{r}70 \\
(4.8)\end{array}$ & $\begin{array}{c}303 \\
(13.5)\end{array}$ & $\begin{array}{r}447 \\
(7.6)\end{array}$ & $\begin{array}{c}19 \\
(2.6)\end{array}$ & $\begin{array}{l}15 \\
(3)\end{array}$ & $\begin{array}{c}76 \\
(10.1)\end{array}$ & $\begin{array}{l}111 \\
(5.7)\end{array}$ & $\begin{array}{l}\text { AF210750 } \\
\text { AF210766 } \\
\text { AF210758 }\end{array}$ \\
\hline 1470 & $\begin{array}{l}\text { France } 1993 \\
\quad 2\end{array}$ & $\begin{array}{c}231 \\
(10.7)\end{array}$ & $\begin{array}{r}81 \\
(5.5)\end{array}$ & $\begin{array}{c}302 \\
(13.4)\end{array}$ & $\begin{array}{c}614 \\
(10.5)\end{array}$ & $\begin{array}{c}57 \\
(7.9)\end{array}$ & $\begin{array}{c}14 \\
(2.9)\end{array}$ & $\begin{array}{c}74 \\
(9.9)\end{array}$ & $\begin{array}{c}146 \\
(7.5)\end{array}$ & $\begin{array}{l}\text { AF210751 } \\
\text { AF210767 } \\
\text { AF210759 }\end{array}$ \\
\hline 22861 & $\begin{array}{l}\text { France } 1998 \\
\quad 8\end{array}$ & $\begin{array}{c}230 \\
(10.7)\end{array}$ & $\begin{array}{c}155 \\
(10.6)\end{array}$ & $\begin{array}{c}294 \\
(13.1)\end{array}$ & $\begin{array}{c}679 \\
(11.6)\end{array}$ & $\begin{array}{c}48 \\
(6.7)\end{array}$ & $\begin{array}{c}31 \\
(6.4)\end{array}$ & $\begin{array}{c}76 \\
(10.1)\end{array}$ & $\begin{array}{l}157 \\
(8)\end{array}$ & $\begin{array}{l}\text { AF210752 } \\
\text { AF210768 } \\
\text { AF210760 }\end{array}$ \\
\hline
\end{tabular}

E282G, as reported previously [4]. These changes are not found in susceptible $S$. pneumoniae strains nor in $S$. mitis, suggesting a role in the initial steps to penicillin resistance $[4,21]$. Isolates 1258 and $\mathrm{BM} 4200$ had short mosaic sequences, AFSRPN or AFSVPN, adjacent to the SSN motif of PBP2B, reflecting replacement of six contiguous residues $(233-238)$. Therefore, these PBPs were products of class A $p b p 2 b$ genes [11]. The other strains had multiple non-consecutive substitutions and presumably had class B $p b p 2 b$ genes, as do resistant serogroup $23 \mathrm{~F}$ strains from England and Spain [11].

A T338A mutation in the STMK motif of PBP2X was found in all the isolates with MICs $>0.5 \mathrm{mg} / \mathrm{L}$ (Fig. 2). By means of site-directed mutagenesis, it has been demonstrated that this substitution plays an important role in determining the binding affinity between serine 337 and the $\beta$-lactam [13]. In strains 1513, 1465 and 1258 , the substitution $\mathrm{Q}$ to $\mathrm{E}$ in position 552 , next to the KSG conserved motif (547-549), is located in the $\beta 3$ strand which spatially borders the active site S-337. This substitution too has been shown to play an additional role in determining the $\beta$-lactam-binding affinity [13]. The PBP2X sequences were almost identical in the most highly resistant isolates, 1470
(MIC $2 \mathrm{mg} / \mathrm{L}$ ) and 22861 (MIC $8 \mathrm{mg} / \mathrm{L}$ ), but additional unique mutations were also found in the latter isolate - these comprised M339F (within the STMK tetrad), A491G and Y595F.

Some isolates displayed particular patterns of PBP alterations. For example, in strain BM4200 (MIC $0.5 \mathrm{mg} / \mathrm{L})$, the peptide sequences of the $p b p 2 b$ and pbp $2 x$ products closely resembled those of isolate 1258, with an AFSVPN block for PBP2B, and of isolates 1470 and 22861 for PBP2X. Although not proven, this suggests that these strains have emerged via independent distinct genetic events. The high penicillin resistance of isolate 22861 (MIC $8 \mathrm{mg} / \mathrm{L}$ ) is the consequence of the accumulation of mutations in the three PBPs, with notable changes around the Cterminus of PBP2B (Fig. 2).

In conclusion, these results show that the emergence of wild-type penicillin-resistant isolates of serotype $23 \mathrm{~F}$ is the consequence of sequential alterations of the three major PBPs. These changes, including both point mutations and recombinations, reflect distinct, cumulative genetic events presumably selected by antibiotic pressure. 


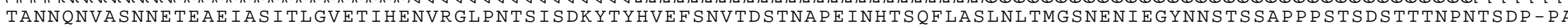

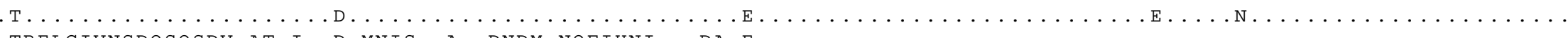

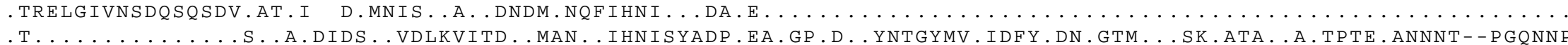

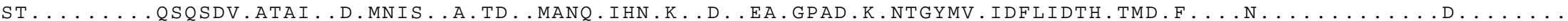

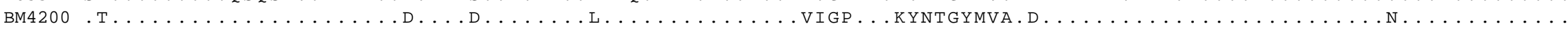

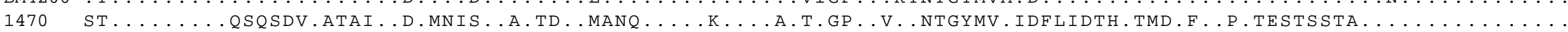

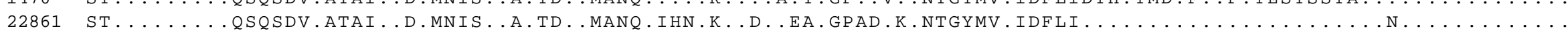

PBP2B

A

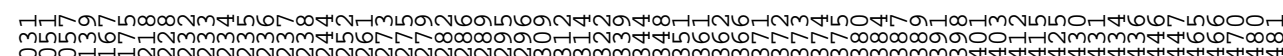

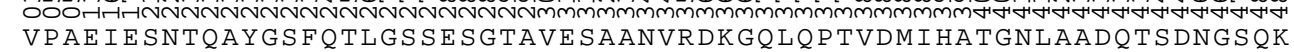
1261

PBP2X

A

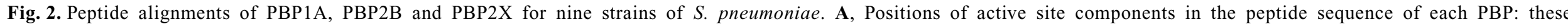

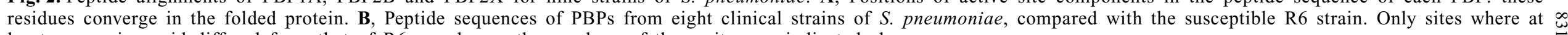
least one amino acid differed from that of R6 are shown; the numbers of these sites are indicated above. 
The GenBank accession numbers of the sequence of pbp $1 a, p b p 2 b$ and $p b p 2 x$ genes of the eight isolates of S. pneumoniae were referred as AF210745-AF210768 (Table 1).

\section{References}

1. Hakenbeck R. Mosaic genes and their role in penicillinresistant Streptococcus pneumoniae. Electrophoresis 1998; 19. 597-601.

2. Hakenbeck R, Grebe T, Zähner D, Stock JB. $\beta$-lactam resistance in Streptococcus pneumoniae: penicillin-binding proteins and non-penicillin-binding proteins. Mol Microbiol 1999; 33: 673-678.

3. Dowson CG, Hutchison A, Spratt BG. Extensive re-modelling of the transpeptidase domain of penicillin-binding protein $2 b$ of a penicillin-resistant South African isolate of Streptococcus pneumoniae. Mol Microbiol 1989; 3: 95-102.

4. Smith AM, Klugman KP. Alterations in penicillin-binding protein 2B from penicillin-resistant wild-type strains of Streptococcus pneumoniae. Antimicrob Agents Chemother 1995; 39: 859-867.

5. Barcus VA, Ghanekar K, Yeo M, Coffey TJ, Dowson CG. Genetics of high level penicillin resistance in cinical isolates of Streptococcus pneumoniae. FEMS Microbiol Lett 1995; 126: 299-304.

6. Dowson CG, Coffey TJ, Spratt BG. Origin and molecular epidemiology of penicillin-binding-protein-mediated resistance to $\beta$-lactam antibiotics. Trends Microbiol 1994; 2: 361-366.

7. Pares S, Mouz N, Pétillot R, Hakenbeck R, Dideberg O. X-ray structure of Streptococcus pneumoniae $\mathrm{PBP} 2 \mathrm{x}$, a primary penicillin target enzyme. Nat Struct Biol 1996; 3: 284-289.

8. Grebe T, Hakenbeck, R. Penicillin-binding proteins $2 \mathrm{~b}$ and $2 \mathrm{x}$ of Streptococcus pneumoniae are primary resistance determinants for different classes of $\beta$-lactam antibiotics. Antimicrob Agents Chemother 1996; 40: 829-834.

9. Hakenbeck R, Kaminski K, Köning A et al. Penicillin-binding proteins in $\beta$-lactam resistant Streptococcus pneumoniae. Microb Drug Resist 1999; 5: 91-99.

10. Ashahi Y, Ubukata K. Association of a Thr-371 substitution in a conserved amino acid motif of penicillin-binding protein $1 \mathrm{~A}$ with penicillin resistance of Streptococcus pneumoniae. Antimicrob Agents Chemother 1988; 42: 2267-2273.

11. Dowson CG, Hutchison A, Brannigan JA et al. Horizontal transfer of penicillin-binding protein genes in penicillinresistant clinical isolates of Streptococcus pneumoniae. Proc Natl Acad Sci USA 1989; 86: 8842-8846.

12. Laible G, Spratt BG, Hakenbeck R. Interspecies recombinational events during the evolution of altered PBP2x genes in penicillin-resistant clinical isolates of Streptococcus pneumoniae. Mol Microbiol 1991; 5: 1993-2002.

13. Mouz N, Di Guilmi AM, Gordon E, Hakenbeck R, Dideberg $\mathrm{O}$, Vernet $\mathrm{T}$. Mutations in the active site of penicillin-binding protein PBP2x from Streptococcus pneumoniae. J Biol Chem 1999; 274: 19175-19180.

14. Reichmann P, König A, Marton A, Hakenbeck R. Penicillinbinding proteins as resistance determinants in clinical isolates of Streptococcus pneumoniae. Microb Drug Resist 1996; 2: $177-181$.

15. Smith MA, Klugman KP. Alterations in PBP1A essential for high-level penicillin resistance in Streptococcus pneumoniae. Antimicrob Agents Chemother 1998; 42: 1329-1333.

16. Geslin P, Fremaux A, Sissia G, Spicq C, Aberrane S. Rapport d'activité (année 1997) du Centre National de Référenc des Pneumocoques, Créteil: Service de Microbiologie, Centre Hospitalier Intercommunal. 1998.

17. Buu-Hoï A, Horodniceanu T. Conjugative transfer of multiple antibiotic resistance markers in Streptococcus pneumoniae. J Bacteriol 1980; 143: 313-320.

18. Ferroni A, Nguyen L, Gehanno P, Boucot I, Berche P. Clonal distribution of penicillin-resistant Streptococcus pneumoniae 23F in France. J Clin Microbiol 1996; 34: 2707-2711.

19. Avery OT, MacLeod CM, McCarty M. Studies on the chemical nature of the substance inducing transformation of pneumococcal types. Induction of transformation by a desoxyribonucleic acid fraction isolated from pneumococcus type III. $J$ Exp Med 1944; 79: 137-158.

20. Martin C, Sibold C, Hakenbeck R. Relatedness of penicillinbinding protein 1a genes from different clones of penicillinresistant Streptococcus pneumoniae isolated in South Africa and Spain. EMBO J 1992; 11: 3831-3836.

21. Dowson CG, Coffey TJ, Kell C, Whiley RA. Evolution of penicillin resistance in Streptococcus pneumoniae: the role of Streptococcus mitis in the formation of a low affinity PBP2B in S. pneumoniae. Mol Microbiol 1993; 9: 635-643. 